\title{
From Critical to Decolonizing Service-Learning: Limits and Possibilities of Social Justice-Based Approaches to Community Service-Learning
}

\author{
Aurora Santiago-Ortiz, J.D. \\ University of Massachusetts
}

\begin{abstract}
Diverging from the traditional approach to service-learning, critical service-learning focuses on the root causes of inequality by addressing power and oppression. By incorporating critical pedagogy in the classroom, and action and reflection outside of it, critical service-learning looks to find solutions to social issues through university - community partnerships. In this article, I review relevant literature that centers social justice-based approaches to critical service-learning and argue that while these approaches are vital to student understanding of oppression, an anticolonial framework is needed to broaden notions of critical service-learning that challenge settler colonial logics. This article engages with the question "Can we decolonize critical service-learning?" and concludes by offering practices, such as solidarity to counter coloniality in higher education, that are responsible to the communities involved in the servicelearning partnership.
\end{abstract}

Community service-learning (CSL) has enjoyed continuous popularity for more than two decades at several educational sites, particularly in higher education (Burth, 2016; Eyler \& Giles, 1999; Furco, Jones-White, Huesman, \& Segrue Gorny, 2016). However, not all CSL programs share the same pedagogy and practice. Much of the traditional servicelearning literature focuses on student outcomes and civic engagement and not on long-term sustainable community impact (Burth, 2016; Crabtree, 2008). In addition, some scholars have challenged the notion that service-learning improves students' academic performance (Furco et al., 2016). Diverging from traditional approaches to service-learning that focus solely on student experiential learning, critical service-learning focuses on the root causes of inequality by addressing power, privilege, and oppression through a social justice-based approach (D. Barrera, Kukahiko, Willner, \& O’Byrne, 2016; Mitchell, 2007).

Critical community service-learning (CCSL) incorporates an explicit acknowledgment of power and systemic inequality in the classroom through critical pedagogy by uncovering the political nature of education, providing deeper reflection on and critique of the supposed neutrality of education and its complicity with structural oppression. However, missing from the extant literature are approaches to CCSL that explicitly address settler colonialism in the United States and acknowledge the inherently colonialist nature of service-learning, including its critical strand. Recent scholarship on critical service-learning calls attention to the colonialist dynamics between those inside academia and those outside of it, but does not directly confront whether service-learning needs hierarchies to justify its very existence.

In this article, I begin to call attention to the question of whether CCSL can be decolonized and begin with a review of some of the recent literature on social justice-based CSL programs. These programs incorporate critical race and feminist theories to interrogate power, privilege, and oppression through CCSL. This review is not meant to be exhaustive. Rather, the articles discussed highlight the absence of a settler colonial analysis and framework in critical service-learning. I then explore what decolonization means and its (im)possibility within CCSL, and present concepts and practices that have the potential to unsettle critical servicelearning and produce work that is answerable to those outside of higher education's walls. These concepts and practices are framed as engagements with CCSL that move toward decolonization, to reframe student-teacher-community relationships in ways that center communities and seek transformation beyond that impacting the students.

\section{Traditional and Critical Notions of Service-Learning}

The traditional model of service-learning is rooted in Dewey's model of experiential learning, and it involves students performing community service and reflecting on that service during class time in connection with content taught as part of the course (Johnson \& Notah, 1999; Kahne \& Westheimer, 1996; Mitchell, 2007). Eyler and Giles (1999) offer 
the following definition of service-learning: "[A]ny program that attempts to link academic study with service," including "non-course-based programs that include a reflective component" and "learning goals" (p. 5). Many schools have incorporated service as a compulsory element, sanctioned by school districts and federal programs that maintain the status quo (Johnson \& Notah, 1999; Kahne \& Westheimer, 1996). Academic fields such as science, technology, engineering, and mathematics (STEM) utilize service-learning to prepare students for the job market and to provide certain communities, which are not always underprivileged or oppressed, with a solution to a short-term necessity, effectively perpetuating a neoliberal model for higher education, driven more by economic growth than social justice (Giroux, 2011).

The goals of traditional service-learning are student-focused and outcomes-based, and this vision has been challenged for reinforcing unequal power dynamics, engaging with community issues superficially, and providing temporary solutions that do not address oppressive conditions (D. Barrera et al., 2016; Mitchell, 2008; Wade, 2001). Service-learning typically focuses on helping those who lack the resources for food, shelter, education, and other basic rights, and it is perceived as meeting individual needs but not usually as political action intended to transform structural inequalities (Kahne \& Westheimer, 1996; Mitchell, 2007; Rosenberger, 2000).

While traditional service-learning employs a charity-based approach to working for communities, critical service-learning takes a social justice turn, analyzing the root causes that necessitate service. It questions the distribution of power, uncovers and centers political notions inherent in service-learning, and focuses on communityuniversity relationships (Mitchell, 2007). CCSL broadens student-focused outcomes to include self-awareness of one's own identity, changing attitudes, and perceptions about the "other" (those in disadvantaged economic and social positions), and it seeks to improve the students' knowledge of those subaltern peoples for the students' benefit and increased cultural awareness (D. Barrera et al., 2016; Yoder Clark \& Nugent, 2011).

CCSL is defined by Hayes (2011) as "experiential learning that empowers people to recognize, expose, and eradicate the social injustices that structure their lives within a hegemonic social order" (p. 48). Mitchell (2008) notes critical service-learning's potential for achieving "political and social reform" (p. 51), whereas Porfilio and Hickman (2011) view critical service-learning as a political project; yet, they do not share a reformist view. However, Porfilio and Hickman agree with Mitchell's (2008) and Marullo's (1999) assertion that service-learning can be both a revolutionary and a liberatory pedagogy that challenges institutional oppression and the status quo. O'Grady (2000) contends that without a social justice focus, service-learning can "perpetuate racist, sexist, or classist assumptions about others and reinforce a colonialist mentality" (p. 12). However, we must be attentive to the ways social justice inserts discourses of decolonization without regard for "how decolonization wants something different than those forms of justice" (Tuck \& Yang, 2012, p. 2). This article further examines this distinction within CCSL to reassert that decolonization is not a metaphor and should be grappled with in any project that seeks to throw into relief the ways that coloniality operates within higher education, including CCSL (Patel, 2016; Tuck \& Yang, 2012). Before I explore this distinction, however, I will look at some of the theoretical foundations that undergird CCSL as well as review some of the empirical literature on CCSL that incorporates a social justice lens.

\section{Critical Pedagogy's Influence on Critical Service-Learning}

Brazilian pedagogue Paulo Freire (1970/1996) is perhaps the best-known critical educator. Pedagogy of the Oppressed (Freire, 1970/1996) has been influential to the work of many critical educators who address power and the political in schooling. Crabtree (2008) and Deans (1999) consider Freire's work to be "one of the theoretical anchors" for service-learning (Crabtree, 2008, p. 27). Freire's work is grounded upon re-creating knowledge through co-intentional education between students and teachers and praxis (or action) and reflection, resulting in transformation. Thus, many critical service-learning programs integrate a critical reflection component during and after the servicelearning process (Mitchell, 2007). Nonetheless, critical pedagogy and Freire himself have been criticized for not including a critical analysis of education that incorporates gender and race, instead focusing solely on a class-based analysis (Ellsworth, 1989; hooks, 1994; Kenway \& Modra, 1992; Mohanty, 2003). A. E. Green (2001) has called for a race and class analysis (without mentioning a gender analysis) in CCSL, and she has advocated for the inclusion of the community in course design to openly address power differentials between community-university partnerships.

There is also the issue of whether the applica- 
tion of Freire's conscientization model to CCSL is appropriate to begin with. Freire developed the model when working with Brazilian peasants, which is a context different from a college classroom, to say the least. Holohan (2017) has pointed to the fixed and essentializing notions of oppressor and oppressed in Freire's work, which lacks nuance in how it details "differences in the way ... individuals may experience oppression and also ignores the possibilities for overlapping forms of oppression" (pp. 448-449), where an individual may experience different forms of oppression and privilege simultaneously. In a CCSL context, students may hold both privileged and targeted identities (oppressor and oppressed), yet reach critical consciousness through the experience of service-learning. This still places the onus on communities to teach students about "real world systemic inequality" through the lens of their experience. Stoecker (2016) has pointed out that Freire's pedagogy was not designed or meant for the classroom, and there are challenges to incorporating this model in a college classroom. Some of these challenges include the restraints of the academic calendar and the reinforcing of inequality through placing students in problematic service agencies.

Freire's work has been co-opted or "domesticated" through a one-size-fits-all application to all people in all contexts (Mayo, 1993). Those involved in a service-learning relationship are imbricated in dynamics of domination and subordination, stemming from colonial, capitalist, sexist, and racist forms of social reproduction. The mere option of being able to take part in service-learning in a university context already creates a hierarchical relationship that places knowledge, power, and choice of service site with those who possess university resources. This hierarchy, constituted prior to the service-learning relationship, is not synonymous with Freire's teachings. Yoder Clark and Nugent (2011) have pointed out that Freire's work "helps us understand the importance of developing an explicit awareness of one's personal power through service-learning" (p. 4). For students coming from privileged groups, a critical awareness of one's own identity "helps those from the dominant community understand and address power imbalances within the service experience" (A. E. Green, 2001; Madsen Camacho, 2004; Yoder Clark \& Nugent, 2011, p. 11). Yet, even if the incorporation of action and reflection provides students with an awareness of the oppression of others, learning for the student is still produced through the refracted lens of the experience of the "other."

\section{Social Justice-Based Approaches to CCSL}

\section{Power, Privilege, and Oppression in Critical Service-Learning}

CCSL has been a site for social justice-based approaches that address power and oppression, intentionally engaging in horizontal, mutually beneficial partnerships. Shabazz and Cooks (2014) acknowledge service-learning as a site that reinscribes colonialist relationships by privileging dominant epistemologies while also reinforcing the status quo. As a counter-approach, Shabbaz and Cooks have explored the possibility of an asset-based approach to CCSL. Through a CCSL media project that partnered a university with a nearby middle school, the authors integrated critical race theory and critical pedagogical frameworks into the project. University students enrolled in a communications course created an in-school and after-school media literacy program to be implemented at a middle school focusing on topics such as race, ethnicity, and nationality. At the end of the program, the students presented their media projects to their school, parents, university, and community (Shabazz \& Cooks, 2014, p. 72). During the CCSL course, attention was given to how deficit discourses are perpetuated in relation to communities and the students served, and these narratives were opposed through counterepistemologies such as critical race theory, which draws on and centers those at the margins (Shabazz \& Cooks, 2014, p. 74).

Drawing on empirical material including undergraduate students' journal entries, program session videos, self-reflections, pre-program focus sessions with middle school participants, and videotaped interviews, Shabazz and Cooks analyzed how asset-based approaches to framing discussions affected all the stakeholders involved in the CCSL project. Shabazz and Cooks asked the students to create an asset map and later to reflect on whether the language used promoted deficit- or asset-based discourse. Their study found that the sixth graders felt that they could discuss or "teach" their peers or family about race (p. 79). White university students in particular were reflexive about their own positionalities and privileges. The projects themselves facilitated relationships between the community and university, which allowed for easier conversations about assets.

An asset-based approach takes into account the existing knowledge and strengths of communities (K. Green, 2014), instead of framing minoritized groups as lacking or "in need of being saved from themselves" (p. 155). However, Stoecker (2016) 
has suggested that it is unclear whether "institutionalized service-learning actually practices an asset-based approach or just espouses it" (p. 71). Stoecker has further pointed out that asset-based approaches are just neoliberal logics in disguise, reinforcing the belief that all that communities have to do "is mobilize those assets and they will be successful in life" (p. 73). If they are not successful, the community is at fault.

Mitchell (2007) studied a social justice-based critical service-learning program at a university over the course of two years. The program studied is aimed at preparing students to be active change agents and to understand social justice theories and foundations. The students participated in a variety of activities such as facilitating classroom discussions with social justice content, writing reflections on topics such as power and privilege, and implementing and later presenting a community service capstone project over the course of four semesters. The capstone proposed a long-term change for a community problem beyond the service term (p. 103).

During the coursework, community voices were brought to challenge unequal power relations between the university and the community and to participate in knowledge production (p. 103). The students also had agency in content selection and class facilitations, and they read a variety of texts that were social justice-based. Fewer than 20 students participated in the program, allowing for a more intimate, cohort-based community building. Mitchell found that all the student participants increased their understanding, learning, and commitment to social justice through their participation in the program.

Contrary to Shabazz and Cooks' (2014) framing of their CCSL program, the program that Mitchell examined employs a deficit-based approach to identify a community problem. Mitchell (2007) states: "[S]tudents must first come to believe and understand that the current community is somehow flawed" (p. 102). While deficit models "emphasize what a particular student, family, or community is lacking to explain underachievement or failure," "damage research is distinct in being more socially and historically situated" (Tuck, 2009, p. 413). Stoecker (2016) has raised the important question of "whether needs or assets are our only choices, or whether they are different choices at all" (p. 90).

Tuck (2009) provides a useful analysis of prevailing damage-centered narratives regarding marginalized communities, whether indigenous and/or urban. She argues that research on communities has been focused on presenting them as "broken and conquered" (p. 419) and urges those engaged in research with communities to consider the "com- plexity, contradiction, and the self-determination of lived lives" (p. 416) through a desire-based framework. By reframing the way researchers work with communities, we can counter the narratives that reseat communities as unable to resist dehumanization. Critical service-learning is not exempt from tropes that view communities through either deficit or damaged-based lenses, and I extend an invitation to rethink and recast the ways we frame these critical projects.

\section{Race, Power, and Privilege in Critical Service- Learning}

Discussing the dynamics of a course she taught in a university, Madsen Camacho (2004) acknowledged the inherent asymmetrical power conditions between those who serve and those who receive the service. The students in her class were placed in one of three sites: a migrant halfway house, a migrant services provider (offering food, supplies, and religious services), and a community or educational center that offered medical and educational services to transitory and new migrants. The data consisted of written reflections, classroom discussions, debriefing sessions, and other texts. The textual reflections included poems, essays, and prose, among others, and three themes arose from the data produced by the students. The first was that migrants were reified by the students' tourist gaze; the second was that the students felt like the "other"; and the third was the students' openness to looking at privilege (pp. 37-38). Madsen Camacho concludes by warning of the dangers of power differentials, between students and community as well as between faculty and students. She also stresses the importance of collaboration in the classroom as well as the importance of acknowledging the "counter-stories" of students in the context of service-learning (Solórzano \& Yosso, 2002).

A. E. Green (2001) explored race within a tutoring program between her university's writing center and a local middle school. The students at the middle school were predominantly African American, while the university students came from a predominantly White institution (PWI). In Green's class, the students were urged to reflect on race and class. Green notes: "[r]ather than assuming that the university automatically knows what is best for an inner-city community, we must unlearn our largely white, middle class biases" (p. 19). Written in 2001, this article reflects the problematic language that was used to refer to densely populated cities ("inner cities"), with racially coded connotations often euphemistically used to mean Black, Brown, and/or Indigenous youth. 
Throughout the course, Green sought to advocate for critical reflection through student response papers that fostered a structural analysis of racism, so that the students could "recognize that the playing field is not level and, hopefully, think beyond their own service-learning experience to the larger structural change" (p. 20). This approach also included visiting an agency that provides services to people experiencing homelessness to create a "sense of safety" (p. 21). Through interpretation of images created by people experiencing homelessness, Green provided a platform for the students to build relationships among themselves. However, in doing so, the project produced an othering gaze meant for the students' benefit.

\section{Feminist Approaches to Critical Service-Learning}

Williams and Ferber (2008) started Smart-Girl, a feminist model and pedagogy in service-learning, with the goal of "improving the lives of adolescent girls in their community" by focusing on collaboration and group dynamics (p. 47). As part of the initiative, university and high school women taught 12 to 15 middle school-aged girls in a variety of settings: day-camps, after-school programs, or a partner nonprofit organization. The program employed a curriculum that covered topics such as peer pressure, body image, and sexual harassment through experiential learning and a curriculum built around teaching life skills. Research on Smart-Girl found that both the guides and the participants benefited from the program. Through journal reflections, the guides expressed that the program had a profound impact on their lives, and many students continued to be involved with the program after the course ended.

Feminist pedagogy emerged as a critique of the "absence of gender as a . . category of analysis in most pedagogical theory" (Luke \& Gore, 1992, p. 8). Incorporating a feminist pedagogy into critical service-learning means interrupting "sexist, patriarchal, and phallocentric knowledge systems" that value patriarchal knowledge as the "master narrative" (p. 196). I extend this critique to note the exclusion within feminist critical pedagogy of genderqueer, gender non-conforming, transgender, and two spirit voices, among other non-binary identities. Gender continues to be mainly viewed as masculine/feminine, thus creating the need to carve out spaces for marginalized groups within those margins to best engage in anti-oppression education within service-learning.

A blog created by Jennifer Ansley (2015) details how queer and feminist pedagogies were integrated into a service-learning project. The students reflected "on the discourses of LGBTQ identity and com- munity being produced by a wide range of archival projects" (Ansley, 2015). The community partner was able to provide input on the design of the project, and the students concluded by reflecting on their own "subject position" regarding their own knowledge production as well as in relation to their community partners (Ansley, 2015). This form of service-learning respects the agency of both the student and the community, allowing for both to be integral to the decision-making process of research. By integrating a queer and feminist perspective, the students were exposed to "a theoretical understanding of intersectional identities and privilege that shape one's institutional location and access to resources" (Ansley, 2015). Ansley also emphasizes the critical reflective aspect of incorporating a queer and feminist studies lens to service-learning, being mindful of the impact and burden these projects place on the community, as well as acknowledging the "students' varying investments, for better and for worse, in the service they're providing" (Ansley, 2015).

\section{Moving toward Decolonizing Critical} Service-Learning: Anticolonial Engagements

The aforementioned studies provide an overview of social justice-based approaches to servicelearning that incorporate a critical lens to interrogate power, privilege, and oppression. Most of the approaches have been student-focused, often dealing with one aspect of identity, mainly race, class, or gender. Framing the issues of oppression in CCSL as intersectional might provide a more holistic approach to the realities communities face, while also working toward breaking hierarchies in the relationship between students, teachers, and community.

If critical service-learning aspires to change unequal power dynamics and to create social change, it must look beyond a critique of power, privilege, and oppression. It must interrogate its own justice agenda, what conceptualizations of justice are being employed, which ones are being left out, or "what it lacks" (Tuck \& Yang, 2016). Service-learning programs often ignore the colonialist nature of servicelearning itself, where the university inserts itself in a community, completes a short-term service project, and then leaves. Perhaps this modus operandi is intentional, as it reinforces the neoliberal agenda of the university, which caters to market value, treating higher education as a means to "power, profit, and achievement" (Brown, 2015, p. 188).

CCSL addresses power relations in society and, in some cases, in the service-learning relationship itself. However, notably absent from the literature 
reviewed in this article is an acknowledgment of settler colonialism within CCSL. More often than not, the social justice-oriented frameworks within CCSL exclude a critique of settler colonialism. As we do not "live single-issue lives" (Lorde, 2007, p. 138), CCSL with a liberatory or anti-oppressive purpose must include Indigenous and decolonial theories. Before I address the question of whether it is possible to decolonize CCSL, I will highlight Arvin, Tuck, and Morrill's (2013) definition of settler colonialism, which the authors define as "a persistent social and political formation in which newcomers/colonizers/settlers come to a place, claim it as their own, and do whatever it takes to disappear the Indigenous peoples that are there" (p. 12). However, not all decolonizing perspectives adhere to this definition when engaging in epistemic ruptures that resist privileging neoliberal, individual, White, male, heterosexual, and Western ways of being and knowing.

\section{Can We Decolonize Critical Service-Learning?}

Decolonizing perspectives in education are not a panacea, but rather must start with the notion of decolonization as well as the locus of analysis. For the purposes of this article, these perspectives are located in Turtle Island, which includes what is now called Canada and the United States. Tejeda, Espinoza, and Gutierrez (2003) have put forth a decolonizing pedagogical praxis that recognizes the connection between colonialism and capitalist domination and exploitation while also articulating a notion of social justice that seeks to dismantle internal colonialism. This praxis engages in action and reflection to transform oppressive conditions, echoing a Freirian vision (Freire, 1970/1996; Tejeda et al., 2003). It is guided by antiracist, antihomophobic, and antisexist values, and is theoretically informed by critical race theory, critical pedagogy, postcolonial studies, and spatial theory (Tejeda et al., 2003).

Although Tejeda and colleagues recognize the plurality of non-White oppressed groups such as Indigenous and African slaves, these groups do not experience colonialism in the same way; hence, decolonization is not achieved the same way. Indigenous scholars would argue that there is no such thing as postcolonial theory in relation to indigeneity, because the structure of settler colonialism persists and continues to seek the erasure of indigenous people (Daza \& Tuck, 2014).

Decolonization goes beyond "freeing your mind" or developing a critical consciousness (Tuck
\& Yang, 2012). Tuck and Yang have argued that "[u]ntil stolen land is relinquished, critical consciousness does not translate into action that disrupts settler colonialism" (p. 19). In other words, it is "a move to innocence," a strategy that reseats settler colonialism, equating decolonization with social justice (Mawhinney, 1998; Tuck \& Yang, 2012). Furthermore, Tuck and Yang argue that decolonization has become an empty signifier when in reality it is incommensurable with other social justice struggles. Decolonization, when used as a metaphor for social justice, ignores the ways that social justice projects can and do reinforce settler colonialism and the ways people, including nonNative people of color, benefit from and participate in the project of settler colonialism. Grappling with these incommensurabilities illuminates the distinctness of decolonization: "[it] doesn't have a synonym" (p. 3).

As service-learning practitioners, it is evident that we cannot currently do what Tuck requires of decolonization, namely, rematriate Native land (Tuck, 2011; Tuck \& Yang, 2012). What can we do, then, to move toward decolonizing servicelearning? To be answerable and responsible to the communities that we work with outside higher education (Grande, 2018; Patel, 2016), CCSL must be unsettled to parse out the inherent contradictions that are constitutive of service-learning. Rather than being prescriptive, I argue that a commitment to taking an anticolonial stance in CCSL as a form of epistemic disobedience is needed (Mignolo, 2009). This stance requires (a) the acknowledgment of settler colonialism as a distinct and continuing structure in academic spaces and beyond, (b) incorporating anticolonial and decolonizing methodologies that counter and resist dominant narratives in CCSL as well as (c) a relational shift in the way that community-university partnerships are envisioned (Grande, 2018).

Patel (2016) has opted for an anticolonial stance in educational research, given that decolonization "should always address material changes" (p. 7). This analysis of decolonizing educational research can be extended to CCSL, particularly when CSL programs are researched regarding their impact on students as well as communities. CCSL programs should interrogate the ways coloniality creates and perpetuates hierarchies in the form of race, class, gender, and other social groups "to serve accumulation of material and land" and further the settler colonial project (Patel, 2016, p. 7). These very hierarchies, at the very least, should be rendered visible in CCSL. 
The Acknowledgment of Settler Colonialism as a Structure in Academic Spaces and beyond

Settler colonialism operates "as through internal/ external colonial modes simultaneously because there is no spatial separation between metropole and colony" (Tuck \& Yang, 2012, p. 5), similar to what M. Barrera (1979) has defined as internal colonialism. Internal colonialism is "a form of colonialism in which the dominant and subordinate populations are intermingled, so that there is no geographically distinct 'metropolis' separate from the "colony"' (p. 194). Tejeda and colleagues (2003) broaden the concept of "internal neocolonialism" to recognize contemporary conceptions of domination and oppression, but they do not name explicitly the centrality of land within a neocolonial context (p. 15). They instead argue that colonialist relations and ideologies are reproduced both in the classroom and through curricula, offering as a solution an anticolonial and decolonizing pedagogical praxis that develops critical consciousness of "our internal neo-colonial condition" to transform said conditions by examining the historical contexts that have produced them (p. 33).

Arvin and colleagues (2013) posit that "relationships to settler colonialism . . . are issues that are critical to social justice and political work that must be addressed" (p. 19). To acknowledge settler colonialism in a social justice context within CCSL requires unpacking students' normative notions about the populations they serve and the relationship the service-learning sites hold to the land they are on themselves. However, as Patel (2016) has argued: "calling attention to something does not automatically mean its transformation" (p. 2). To move toward decolonization in CCSL requires grappling with the centrality of land for Indigenous people and understanding our positionalities as either settlers, the colonized, or both (Patel, 2016). This means understanding the role of place in CSL: how place and land are inextricably linked to Native struggles for sovereignty. The acknowledgment of settler colonialism also means engaging in an analysis of the process of colonialism itself, its impact in the academy and broader society and institutions, and how it affects community-university partnerships (Smith, 2012). This analysis involves the decentering of Western, Eurocentric narratives that formulate Indigenous people and land as discoverable or conquerable. Bolstered by the ideals of the Enlightenment, these dominant narratives create racialized and gendered hierarchies that place those that do not possess privileged identities in need of receiving "community service" for the benefit of those "learning." For those that "choose the margins" (hooks, 1990; Smith, 2012) and are committed to ethical and relational research with communities, Linda Tuhiwai Smith (2012) outlines a number of methodologies that facilitate reciprocity, mutuality, and authenticity, such as participatory action research, oral histories, and testimonios. These methodologies constitute the second anticolonial engagement I propose and are consistent with anticolonial stances that center those traditionally excluded from spaces of knowledge production and from whom CCSL can largely benefit.

The third engagement I propose is solidarity as anticolonial praxis. Solidarity has been a ubiquitous concept in a variety of contexts: political, religious, and feminist discourses, to name a few. Although solidarity has been used as a homogenizing term that evokes a discourse of unity that eschews difference, it is neither all-encompassing nor a panacea (Dean, 1997). The construct of solidarity I propose draws on decolonizing and feminist perspectives (Gaztambide-Fernández, 2012; Mohanty, 2003) and is useful in envisioning what an anticolonial stance in CCSL can look like; as a relational ethic, solidarity presents a possibility for more reciprocity and mutually-beneficial relationship building between students and communities. As an anticolonial practice, solidarity goes beyond short-term goals because it involves the unraveling of Western, Enlightenment rationalities that "privilege the individual over community" (Tuck \& McKenzie, 2015, p. 152), outlasting the temporality of the experiential learning experience.

\section{Solidarity as Anticolonial Praxis}

As a concept, solidarity is ever-present in Freirian pedagogy, yet it is under-theorized in education (Gaztambide-Fernández, 2012). Freire's $(1970 / 1996)$ view of solidarity is one that allows people from different social locations to work together in transforming social conditions. He described solidarity as requiring

that one enter into the situation of those with
whom one is solidary; it is a radical posture ...
true solidarity with the oppressed means fight-
ing at their side to transform the objective re-
ality which has made them these "beings for
another." (Freire, 1970/1996, p. 49)

Gaztambide-Fernández (2012) has referred to solidarity as "particular types of social relations between individuals as well as groups ... from social cohesion to social movements, from political to civic organization, from religious duty to racial 
obligation" (p. 46). These social relations, however, appear to be configured toward a particular goal. Walter Ferreira de Oliveira (2014) has extended solidarity's relational component "to less obvious situations, such as everyday relationships ..." (p. 77). Echoing Freire, de Oliveira views solidarity as a shared struggle "of trying to escape various forms of oppression" (p. 77). These authors view solidarity as relational, yet manifested in the political, social, and religious spheres, among others. Gaztambide-Fernández has suggested solidarity as a possibility for "rethinking educational strategies that might yield different approaches to decolonization" (p. 49). In a critical service-learning context, solidarity requires a commitment to actions that are transformative on all sides of the relationship.

Gaztambide-Fernández (2012) has critiqued some of the uses of solidarity and how these "reinscrib[e] colonial logics and operat[e] to obscure complicity and continued colonization" (p. 41). Solidarity is not decolonization, but it is a way to resist colonial logics because it requires the configuration of new ways of being, interacting, and learning, which together emphasize the collective, the reciprocal, and mutual, rather than individualistic notions of the self. In this case, solidarity becomes an "anticolonial" stance rather than an attempt at decolonization as a metaphor, void of material changes (Tuck \& Yang, 2012). This stance might be better suited to looking toward challenging critical notions of service-learning to question settler colonial and neoliberal logics that operate within those partnerships. These logics position students as extractors of knowledge through the consumption and interpretation of how othered groups experience the effects of colonialism, imperialism, and oppression (Tuck \& Yang, 2012).

South Asian scholar and feminist Chandra Talpade Mohanty (2003) has defined solidarity "in terms of mutuality, accountability, and the recognition of common interests as the basis for relationships among diverse communities" (p. 7). It is the kind of relationship that is built on trust, humanity, and resistance, "foreground[ing] communities of people who have chosen to work and fight together," and it prioritizes difference and diversity (p. 7). She has constructed a feminist, anticapitalist decolonizing pedagogy that interrogates how the West and its others are taught so that, like Freire's (1970/1996) pedagogy, "education becomes the practice of liberation" (p. 200).

Before we entirely reject solidarity, it is first necessary to untangle solidarity's porous significance and potential for creating a path toward liberation and decolonization. It remains critical to make a case for embracing solidarity while simultaneously being uneasy about the assumptions it sometimes evokes (Roediger, 2016). Roediger reminds us to interrogate whether "solidarity is always a good thing, to recall what and whom solidarity leaves out," as some view solidarity as premised on these exclusions (p. 224). Roediger further implores us to interrogate how solidarity works across oppressions and to take a nuanced, intersectional approach to it. South Asian activist and educator Harsha Walia (2015), as well as Tuck and Yang $(2012,2018)$, is critical of solidarity precisely because of its erasure of indigenous struggles that are incommensurable with other social justice struggles. Tuck and Yang (2018) have offered "contingent collaborations" as an alternative to solidarity, rooted in an "ethic of incommensurability," which acknowledges the possibility of collaboration for a certain period of time "even while anticipating that our pathways toward enacting liberation will diverge" (p. 2).

In keeping these critiques of solidarity in mind, my aim is to present a construct of solidarity that calls for working for social transformation collectively and interdependently. However, interdependence is not a call for erasure and the silencing of differences in favor of a "common good." Solidarity as an anticolonial engagement requires working and acknowledging differences, along with linking "knowledge, social responsibility, and collective struggle" (Mohanty, 2003, p. 201). In the context of critical and anticolonial approaches to servicelearning, dialogue can serve as a conduit to explore difference and we use it as a strength in building relationships and coalitions (Collins \& Bilge, 2016). hooks (1994), as a champion of dialogue, believes that " $[t] o$ engage in dialogue is one of the simple ways we can begin as [people], teachers, scholars, and critical thinkers to cross boundaries," the barriers that may or may not be erected by race, gender, class, professional standing, and a host of other differences (p. 130). Creating sustained dialogic spaces allows for the exposure of points of connection, as well as the rough edges of difference.

\section{Conclusion}

Thus far, I have presented critical approaches to service-learning that have foregrounded power, privilege, and oppression in their projects. These approaches are rooted in social justice and seek to analyze the systemic underpinnings of oppression and its manifestations. Yet, if they are to be intersectional and socially transformative, they cannot amplify the voices of some while erasing others. An anticolonial stance in critical service-learning requires us to look at our own positionality and relationship to colonialism and knowledge, and it 
implores us to challenge the reproduction of colonialist structures in community-university relations (Patel, 2016). Before engaging with students' complicity or relationship with settler colonialism, however, the students should first explore, inquire, and think critically about the intersections of what is Western, modern, or Indigenous, engaging in "the politics of knowledge production" (Nakata, Nakata, Keech, \& Bolt, 2012, p. 121). In other words, as Freire and many critical scholars have argued, we must develop a critical consciousness, or "an awakening from the slumber of hegemony, and the realization that action has to occur" (Smith, 2012, p. 201). Perhaps before, in preparation for, and during service-learning, we should embrace the "pauses" (Patel, 2016) to understand what we can do to disrupt hegemonic, hierarchical practices in critical service-learning to take a solidary, anticolonial stance.

Nonetheless, Nakata and colleagues (2012) remind us that there are limits to students' engagement with decolonial analyses, and these limits should be noted in learning spaces to understand that some social justice struggles have aims that are incompatible with decolonization. Patel (2016) has suggested a moratorium on the term "social justice" in educational research because it has "become a vehicle for settler logics and heteropatriarchal capitalism" (p. 88). Patel's suggestion unsettles the concept of social justice and necessitates the unearthing of underlying "heteropatriarchal racist logics of individuality" which cannot undo coloniality because they are reinscribed by those logics (p. 90). These logics create the conditions for the elimination of Indigenous people and the theft of Indigenous land (Grande, 2018).

Coloniality implicates us all, and the university is no exception. In fact, the university serves as a bulwark of settler and other forms of epistemic colonialism. For those of us "doing" the work of social justice education through critical servicelearning, we must ask ourselves: What role do we play in perpetuating colonizing logics? How do we "reimagine the conditions for ethical encounters with others that challenge present conditions of colonization and inequality" (Gaztambide-Fernández, 2012, p. 50)? I recognize that this article affords many more nuances than I have presented; nevertheless, it is a point of departure. Leaning into the complexities of critical service-learning can help carve out the space needed to ask questions such as: Who is being centered in these CSL projects? Whose knowledge is being produced, expanded, or limited? What logics are being reinforced through these CSL projects? Which theories of change, or "beliefs or assumptions about how social change happens, is prompted, or is influenced," are being employed within these projects (Tuck \& Yang, 2014, p. 125)?

For example, projects that look toward decolonization can engage in "questioning common settler colonial tropes that erase the complexity of Indianness" (Daza \& Tuck, 2014, citing Calderon, 2014, p. 332). By questioning these tropes, CCSL can begin naming and opposing settler colonial logics and practices (Patel, 2014). Methodologically, careful attention should be paid to the ways communities and students work together. Critical Indigenous scholars and scholars of color have pointed out that the project of coloniality, or "the manner in which modem systems of colonialism operate epistemically" (Calderón, 2014, p. 314), continues to operate through narratives of ownership over knowledge production. An anticolonial stance to CCSL questions whether the service-learning projects that are to be undertaken are complicit in furthering these settler colonial narratives, either through the curriculum or through praxis.

Similarly, service-learning, in its "learning" component, is also concerned with the production of knowledge, but it is focused on the students. Thus, CCSL should be accountable for the ways learning happens, ensuring that all involved are equal participants in all stages of the process. Decisions about the kind of project that will be developed and implemented and the project's objectives should be decided with the involvement of the community partner. By countering top-down, hierarchical processes that privilege the student agenda in service-learning, we can move toward reciprocity and, ultimately, solidarity in service-learning.

Pausing to ask ourselves these questions is a step toward making critical service-learning responsible to the ways colonialist relationships are maintained in both critical and traditional service-learning models. Solidarity, as an anticolonial stance, is a possible way to relate across difference that challenges individualistic social configurations. This is especially important within the realm of servicelearning, where horizontal relationships are essential to laying the foundation for sustainable social change.

With the recent shift of global politics to the right and the ever-present neoliberalization of higher education, there is a need to envision pedagogies that disrupt complicity with the neoliberal and settler colonial project in education. This means identifying settler logics that seek to assimilate communities into traditional or status quo discourses, or those that seek to flatten differences by homogenizing struggles in social justice-driven programs in higher education. This article has called attention 
to the ways that service-learning furthers the settler colonial projects and has argued for anticolonial engagements that recognize settler colonialism as a permeating structure. Perhaps service-learning requires shifting its "service" approach to a more horizontal and solidary community-university partnership. The former implies a hierarchical relationship from the outset, and the latter opens the door for epistemic disobedience that transgresses colonialist understandings of knowledge and relationships.

\section{Acknowledgments}

The author would like to thank the anonymous reviewers for their generous feedback, Korina Jocson for her comments, Ximena Zúñiga for understanding the importance of solidarity, and Jorell Meléndez-Badillo, Libertad Brouhns-Santiago, and Blanca Ortiz Torres for their unconditional support.

\section{References}

Ansley, J. (2015, June 10). A queer and feminist approach to service learning in the $21 \mathrm{C}$ writing classroom. Retrieved from https://sites.duke.edu/ lamptwp/2015/06/10/a-queer-and-feminist-approachto-service-learning-in-the-21c-writing-classroom/

Arvin, M., Tuck, E., \& Morrill, A. (2013). Decolonizing feminism: Challenging connections between settler colonialism and heteropatriarchy. Feminist Formations, 25(1), 8-34.

Barrera, D., Kukahiko, K. I. T., Willner, L. N., \& O’Byrne, K. (2016). Realizing a critical framework for service-learning at an American Public Research University. In K. M. Soria \& T. D. Mitchell (Eds.), Civic engagement and community service at research universities: Engaging undergraduates for social justice, social change, and responsible citizenship (pp. 203218). Basingstoke, UK: Palgrave Macmillan.

Barrera, M. (1979). Race and class in the Southwest: A theory of racial inequality. Notre Dame, IN: University of Notre Dame Press.

Brown, W. (2015). Undoing the demos: Neoliberalism's stealth revolution. Brooklyn, NY: Zone Books.

Burth, H. P. (2016). The contribution of service-learning programs to the promotion of civic engagement and political participation: A critical evaluation. Citizenship, Social and Economics Education, 15(1), 58-66.

Calderon, D. (2014). Uncovering settler grammars in curriculum. Educational Studies, 50(4), 313-338.

Collins, P. H., \& Bilge, S. (2016). Intersectionality. Cambridge, UK: Polity Press.

Crabtree, R. D. (2008). Theoretical foundations for international service-learning. Michigan Journal of Community Service Learning, 15(1), 18-36.

Daza, S. L., \& Tuck, E. (2014). De/colonizing, (post) (anti) colonial, and indigenous education, studies, and theories. Educational Studies, 50(4), 307-312.
Dean, J. (1997). Feminist solidarity, reflective solidarity: Theorizing connections after identity politics. Women \& Politics, 18(4), 1-26.

Deans, T. (1999). Service-learning in two keys: Paulo Friere's critical pedagogy in relation to John Dewey's pragmatism. Michigan Journal of Community Service Learning, 6, 15-29.

De Oliveira, W. F. (2014). For a pedagogy of solidarity. In A. M. Aráujo Freire \& W. F. De Oliveira (Eds.), Pedagogy of solidarity (pp. 65-83). Walnut Creek, CA: Left Coast Press.

Ellsworth, E. (1989). Why doesn't this feel empowering? Working through the repressive myths of critical pedagogy. Harvard educational review, 59(3), 297-325.

Eyler, J., \& Giles, D. E., Jr. (1999). Where's the learning in service-learning? San Francisco, CA: Jossey-Bass.

Freire, P. (1996). Pedagogy of the oppressed. London, England: Penguin Education. (Original work published 1970)

Furco, A., Jones-White, D., Huesman, R., Jr., \& Segrue Gorny, L. (2016). Modeling the influence of servicelearning on academic and sociocultural gains: Findings from a multi-institutional study. In K. M. Soria \& T. D. Mitchell (Eds.), Civic engagement and community service at research universities: Engaging undergraduates for social justice, social change, and responsible citizenship (pp. 143-164). Basingstoke, UK: Palgrave Macmillan.

Gaztambide-Fernández, R. (2012). Decolonization and the pedagogy of solidarity. Decolonization: Indigeneity, Education \& Society, 1(1), 41-67.

Giroux, H. A. (2011). On critical pedagogy. New York, NY: Continuum International Publishing Group.

Grande, S. (2004). Red pedagogy: Native American social and political thought. Lanham, MD: Rowman \& Littlefield.

Grande, S. (2018). Refusing the university. In E. Tuck \& K. W. Yang (Eds.), Toward what justice? Describing diverse dreams of justice in education (pp. 47-66). New York, NY: Routledge.

Green, A. E. (2001). "But you aren't White": Racial perceptions and service-learning. Michigan Journal of Community Service Learning, 8(1), 18-26.

Green, K. (2014). Doing double Dutch methodology: Playing with the practice of participant observer. In D. Paris \& M. T. Winn (Eds.), Humanizing research: Decolonizing qualitative inquiry with youth and communities (pp. 147-160). Thousand Oaks, CA: SAGE.

Hayes, K. (2011). Critical service-learning and the black freedom movement. In B. J. Porfilio \& H. Hickman (Eds.), Critical service-learning as revolutionary pedagogy: A project of student agency in action (pp. 4770). Charlotte, NC: Information Age Publishing.

Holohan, K. J. (2017). Identification, language, and subjectivity: Reading Freire through/against Lacan. Curriculum Inquiry, 47(5), 446-464.

hooks, b. (1990). Marginality as a site of resistance. In R. Ferguson, M. Gever, T. T. Minh-ha, \& C. West (Eds.), Out there: Marginalization and contemporary cultures (pp. 341-343). Cambridge, MA: MIT Press. 
hooks, b. (1994). Teaching to transgress: Education as the practice of freedom. New York, NY: Routledge.

Johnson, A. M., \& Notah, D. J. (1999). Service learning: History, literature review, and a pilot study of eighth graders. The Elementary School Journal, 99, 453-467.

Kahne, J., \& Westheimer, J. (1996). In the service of what? The politics of service learning. Phi Delta Kappan, 77(9), 592. Retrieved from http://silk.library. umass.edu/login?url=http://search.proquest.com/ docview/218535850?accountid=14572

Kenway, J., \& Modra, H. (1992). Feminist pedagogy and emancipatory possibilities. In C. Luke \& J. Gore (Eds.), Feminisms and critical pedagogy (pp. 138166). New York, NY: Routledge.

Lorde, A. (2007). Sister outsider: Essays and speeches. Berkeley, CA: Crossing Press.

Luke, C., \& Gore, J. (Eds.). (1992). Feminisms and critical pedagogy. New York, NY: Routledge.

Madsen Camacho, M. (2004). Power and privilege: Community service learning in Tijuana. Michigan Journal of Community Service Learning, 10(3), 31-42.

Marullo, S. (1999). Sociology's essential role: Promoting critical analysis in service-learning. In J. Ostrow, G. Hesser, \& S. Enos (Eds.), Cultivating the sociological imagination: Concepts and models for servicelearning in sociology (pp. 11-28). Washington, DC: American Association of Higher Education.

Mawhinney, J. (1998). "Giving up the ghost": Disrupting the (re)production of white privilege in antiracist pedagogy and organizational change (Master's thesis). Ontario Institute for Studies in Education of the University of Toronto. Retrieved from http:// www.collectionscanada.gc.ca/obj/s4/f2/dsk2/tape15/ PQDD_0008/MQ33991.pdf

Mayo, P. (1993). When does it work? Freire's pedagogy in context. Studies in the Education of Adults, 25(1), 11-30.

Mignolo, W. (2009). Epistemic disobedience, independent thought and decolonial freedom. Theory, Culture \& Society, 26(7/8), 159-181.

Mitchell, T. D. (2007). Critical service-learning as social justice education: A case study of the citizen scholars program. Equity \& Excellence in Education, 40(2), 101-112.

Mitchell, T. D. (2008). Traditional vs. critical servicelearning: Engaging the literature to differentiate two models. Michigan Journal of Community Service Learning, 14(2), 50-65.

Mohanty, C. T. (2003). Feminism without borders. Durham, NC: Duke University Press.

Nakata, M., Nakata, V., Keech, S., \& Bolt, R. (2012). Decolonial goals and pedagogies for indigenous studies. Decolonization: Indigeneity, Education \& Society, l(1), 120-140.

O’Grady, C. R. (2000). Integrating service learning and multicultural education: An overview. In C. R. O'Grady (Ed.), Integrating service learning and multicultural education in colleges and universities (pp. 1-19). Mahwah, NJ: Lawrence Erlbaum.
Patel, L. (2014). Countering coloniality in educational research: From ownership to answerability. Educational Studies, 50(4), 357-377.

Patel, L. (2016). Decolonizing educational research: From ownership to answerability. New York, NY: Routledge.

Porfilio, B. J., \& Hickman, H. (Eds.). (2011). Critical service-learning as revolutionary pedagogy: A project of student agency in action. Charlotte, NC: Information Age Publishing.

Roediger, D. (2016). Making solidarity uneasy: Cautions on a keyword from Black Lives Matter to the past. American Quarterly, 68(2), 223-248.

Rosenberger, C. (2000). Beyond empathy: Developing critical consciousness through service learning. In $\mathrm{C}$. R. O'Grady (Ed.), Integrating service learning and multicultural education in colleges and universities (pp. 23-43). Mahwah, NJ: Lawrence Erlbaum.

Shabazz, D. R., \& Cooks, L. M. (2014). The pedagogy of community service-learning discourse: From deficit to asset mapping in the re-envisioning media project. Journal of Community Engagement and Scholarship, 7(1), 71-83.

Smith, L. T. (2012). Decolonizing methodologies: Research and indigenous peoples. London, England: Zed Books.

Solórzano, D. G., \& Yosso, T. J. (2002). Critical race methodology: Counter-storytelling as an analytical framework for education research. Qualitative Inquiry, 8(1), 23-44.

Stoecker, R. (2016). Liberating service learning and the rest of higher education civic engagement. Philadelphia, PA: Temple University Press.

Tejeda, C., Espinoza, M., \& Gutierrez, K. (2003). Toward a decolonizing pedagogy: Social justice reconsidered. In P. Trifonas (Ed.), Pedagogies of difference: Rethinking education for social change (pp. 10-38). New York, NY: Routledge.

Tuck, E. (2009). Suspending damage: A letter to communities. Harvard Educational Review, 79(3), 409-428.

Tuck, E. (2011). Rematriating curriculum studies. Journal of Curriculum and Pedagogy, 8(1), 1-4.

Tuck, E., \& McKenzie, M. (2015). Place in research: Theory, methodology, and methods. New York, NY: Routledge.

Tuck, E., \& Yang, K. W. (2012). Decolonization is not a metaphor. Decolonization: Indigeneity, Education \& Society, 1(1), 1-40.

Tuck, E., \& Yang, K. W. (2014). Youth resistance research and theories of change. New York, NY: Routledge.

Tuck, E., \& Yang, K. W. (2016). What justice wants. Critical Ethnic Studies, 2(2), 1-15.

Tuck, E., \& Yang, K. W. (2018). Introduction: Born under the rising sun of social justice. In E. Tuck \& K. W. Yang (Eds.), Toward what justice? Describing diverse dreams of justice in education (pp. 1-17). New York, NY: Routledge.

Wade, R. (2001). And justice for all: Community servicelearning for social justice (Issue Paper for Service- 
Learning and Community Service). Denver, CO: Education Commission of the States.

Walia, H. (2015). Decolonize together: Moving beyond a politics of solidarity towards a politics of decolonization. In C. Milstein (Ed.), Taking sides: Revolutionary solidarity and the poverty of liberalism (pp. 40-47). Oakland, CA: AK Press.

Williams, R. L., \& Ferber, A. L. (2008). Facilitating smart-girl: Feminist pedagogy in service learning in action. Feminist Teacher, 19(1), 47-67.

Yoder Clark, A., \& Nugent, M. (2011). Power and service-learning: Salience, place, and practice. In B. Porfilio \& H. Hickman (Eds.), Critical servicelearning as revolutionary pedagogy: An international project of student agency in action (pp. 3-27). Charlotte, NC: Information Age Publishing.
Author

AURORA SANTIAGO-ORTIZ, J.D. (asantiagoort@umass.edu) is a social justice education scholar. She holds a BFA in film and television from New York University's Tisch School of the Arts and earned a Juris Doctor from the University of Puerto Rico School of Law. Her work focuses on liminal epistemologies and critical pedagogies from an intersectional, anticolonial standpoint. Aurora's research draws on de/anticolonial perspectives, womxn of color, and Native feminist scholarship and praxis to address how critical dialogic methods can foster solidarity in community-university partnerships. 